\title{
The Impact of Foreign Ownership and Management on Firm Performance in Vietnam
}

\author{
Thi Xuan Hong NGUYEN', Thu Huyen PHAM², Thi Nhung DAO ${ }^{3}$, \\ Thi Nga NGUYEN ${ }^{4}$, Thi Kim Ngoc TRAN ${ }^{5}$
}

Received: July 03, 2020 Revised: July 25, 2020 Accepted: August 10, 2020

\begin{abstract}
The human and capital resources from foreign investors are important sources of finance for developing countries. Foreign ownership can help the firm to raise funds for operations and the foreign management can help the firm expand the market and improve management. However, does this really happen to Vietnamese firm? To find the answer to that question, this paper examines the impact of foreign ownership and management on the financial performance of listed firms on Vietnam's stock market. The data collected include 427 listed firms in all fields over five years, from 2014 to 2018. The financial performance is measured by Tobin's Q, ROA and ROE. The study carried out testing of each model by the least squares method of Pool OLS, assessing random effects (REM) and evaluating fixed effects (FEM). The most effective model is the FEM model. The results show that the foreign ownership ratio and the size of the firm have a positive impact on the financial performance. The foreign management, the age of the firms, the liquidity and financial leverage have a negative impact on the financial performance. Based on the research results, the study proposes some recommendations to improve the financial performance of listed firms in Vietnam.
\end{abstract}

Keywords: Foreign Ownership, Foreign Management, Financial Performance

JEL Classification Code: G30, M40, M41

\section{Introduction}

Economic growth is an important goal of every country. To achieve and maintain that goal, each country will have policies and steps appropriate to their specific circumstances.

${ }^{1}$ First Author and Corresponding Author. Faculty of Accounting and Auditing, Hanoi University of Insdustry, Vietnam [Postal Address: No 298, Cau Dien Road, Bac Tu Liem District, Ha Noi City, 100000, Vietnam] Email: nguyenthixuanhong@haui.edu.vn

${ }^{2}$ Faculty of Accounting and Auditing, Hanoi University of Insdustry, Vietnam. Email: phamthuhuyen@haui.edu.vn

${ }^{3}$ Faculty of Accounting and Auditing, Hanoi University of Insdustry, Vietnam. Email: daothinhung@haui.edu.vn

${ }^{4}$ Faculty of Accounting and Auditing, Hanoi University of Insdustry, Vietnam. Email: nguyenthinga@haui.edu.vn

${ }^{5}$ Department of Financial and Accounting, Hanoi University of Insdustry, Vietnam. Email: ngocttk@haui.edu.vn

(c) Copyright: The Author(s)

This is an Open Access article distributed under the terms of the Creative Commons Attribution Non-Commercial License (https://creativecommons.org/licenses/by-nc/4.0/) which permits unrestricted non-commercial use, distribution, and reproduction in any medium, provided the original work is properly cited.
However, any country must answer the question of where resources for economic development investment lie and how to mobilize those resources. In the trend toward globalization, in order to survive and develop, each economy must bring into play internal resources in combination with external resources. It has been over 30 years of development since Vietnam carried out economic policies to attract and receive foreign investment capital. By now, the foreigninvested economic sector has been increasingly displaying its important role and significant contribution to the socioeconomic development of the country. Especially, since the Law on Investment No. 67-2014-QH13 officially came into effect in 2015 and the relaxation of foreign ownership was carried out, stable foreign capital flows have been attracted into the Vietnamese stock market. The strong increase in the number of multinational investment flows has promoted economic development in general and the performance of enterprises in particular. In the coming period, Vietnam continues to affirm that the foreign-invested economic sector is an important component of the national economy. This sector is encouraged for long-term development in 
accordance with objectives, strategic orientations and plans of the country's socio-economic development in the medium and long term.

So, how have the foreign investment and foreign management participation contributed to changing the financial efficiency of firms? Within the scope of this article, we use quantitative research methods to collect data on foreign investment, foreign management participation and the impact on the financial performance of listed firms on the Vietnamese stock market.

\section{Literature Review}

When studying the impact of foreign ownership on financial performance, most of the previous studies applied panel data and the following commonly-used research methods: Pooled Ordinary Least Square (Pooled OLS), Fixed Effects Model (FEM) and Random Effects Model (REM); they then drew conclusions based on the most appropriate model. Few studies used the Generalized Method of Moments (GMM). In addition, due to the differences in scopes of studies regarding space and time as well as differences in measurement scales for financial performance, results about the relationship between these two factors are not the same.

In Ukraine, Olga (2009) distinguished the impact of different ownership objects and internal issues of enterprise ownership rights. FEM test showed no link between foreign ownership and financial performance; however, deeper analysis of ownership objects using the GMM method revealed the positive relationship between these factors in firms with invested capital from the group of developed countries. Studies by Chibber and Majumdar (1999) and Douma et al. (2006) used data from foreign-invested companies in India and the cross-sectional regression method to find evidence of the positive impact of foreign investment on ROA and ROE of these firms. Studies by Wei et al. (2004) and Estrin et al. (2009) on firms in China, and studies by Baek et al. (2004) and Park (2004) about firms in Korean were carried out at different times, but all achieved the same result, namely, that foreign ownership has a positive impact on the Tobin's Q and even has more impact than other types of ownership (Wei et al., 2004). When studying Vietnamese firms with the main research methods as Pooled OLS, FEM, REM, or GMM, many authors found evidence of the positive correlation between these factors. For example, $\mathrm{Vu}$ et al (2019), Nguyen and Dang (2017), Dinh and Ho (2017), Nguyen and Pham (2017) showed that foreign ownership in Vietnam has positive impact on financial performance at the significance level of $1 \%-5 \%$. This positive correlation was explained by the authors based on the advantages that foreign investors bring to firms.

In spite of this positive correlation, some studies suggest that foreign ownership positively affects financial efficiency only up to a certain ratio; after that, the increase of foreign ownership ratio does not lead to profit increase for firms. Greenaway et al. (2009) showed the relationship between foreign ownership and performance of firms in China through an inverted-U-shaped graph. Financial performance of firms increased when foreign ownership ratio increased by $47 \%$ to $64 \%$ and then decreased. Firms with controlling foreign ownership ratio of $51 \%$ would achieve outstanding business performance (Douma et al., 2006). This research result is also consistent with the conclusion of a study by Gurbuz and Aybars (2010) about listed companies in Turkey. The study by Park (2002) on industrial firms listed on the Tokyo Stock Exchange showed a linear curve about the relation between Tobin's Q and the foreign ownership ratio. Accordingly, the increase in foreign ownership led to the increase in financial performance; however, when the foreign ownership ratio increased to about $40 \%-45 \%$, financial performance increased, then decreased. This study also showed that, in Japan, big foreign investors often invested in large and well-managed firms. In Vietnam, Nguyen and Nguyen (2013) divided firms into four groups with foreign ownership ratio ranging from $10 \%$ to $49 \%$ to study; they found out that the foreign investment ratio of about $20-50 \%$ would have a clearer positive impact on the ROA of firms, while the ROE would only be affected in firms with foreign ownership ratio of less than $10 \%$.

However, there are many studies with contrasting results about this positive impact (Xu \& Wang, 1999; Abbas et al., 2009). When considering the impact of the ownership structure on the operation of firms in Malaysia, these studies showed that ROE had no correlation with foreign ownership. The analysis by Lee (2008) about the impact of the ownership structure on enterprise value of firms in Korean also suggested that there was no evidence of the impact of foreign ownership on ROA of firms in this country. In Vietnam, the study by Nguyen and Ngo (2017) produced negative results about this relationship in real estate firms. Nguyen (2018) and Doan (2014) stated that the foreign direct investment ratio in general did not show signs of impact on financial performance.

The impact of foreign management also attracts the attention of researchers. Different measurement scales of financial performance like Tobin's Q, ROA, ROE, and ROS all show that, if the executive board has a participation of board members from diverse nationalities, the financial performance will be higher. The studies by Choi et al. (2007) about firms in Korea, and by Saleh et al. (2009) about firms in Malaysia, showed the positive impact of foreign management on financial performance. According to the study by Oxelheim and Randoy (2003) about firms in Norway and Sweden, firms with board members who are British and American nationals had higher Tobin's Q higher 
than other firms. It was explained that foreign management and control improved cooperation in technology, consultancy, marketing arrangements, branding, patent obligations and resource sharing. In addition, the diversity of nationalities also promoted more effective global relationships and competitive advantage by expanding the international network; as a result, the consumption market would be expanded and higher operation efficiency would be achieved (Djankov \& Hoekman, 2000).

Contrary to the positive correlation documented above, Joenoes and Rokhim (2019) showed that the presence of Asian nationality board members had negative impact on the financial performance of firms Indonesia. The authors explained that firms having non-Asian board members mainly had members from developed countries with better experience and management skills than those from Asian countries. The studies by Rose (2007) about firms in Denmark, and by Darmadi (2011) about firms in Indonesia, did not find empirical evidence of the positive correlation.

From the review of the empirical studies above, we find that the studies about the relationship between foreign ownership ratio and management with financial performance will yield different results when carried out in different research areas. As a developing country, Vietnam has issued a range of policies to encourage foreign investment flows, especially since the Law on Investment 2014 came in effect. How will foreign ownership and management affect the financial performance of firms? The authors have collected data from firms on the Vietnamese stock market to find the answers to this question.

\section{Data and Research Methods}

\subsection{Background Theory}

\subsubsection{Ownership Theory}

The theory of ownership suggests that the difference in ownership will affect owners' motivation and behavior (Alchian \& Demsetz, 1973). This theory emphasizes the concentration of ownership in the form of private ownership, which will motivate management to create better business efficiency than the dispersion of public ownership. The private sector will have better operational efficiency than the state sector. According to Alchian and Demsetz, private ownership can improve the relationship among motivation, interests and behaviors of owners, executives and employees. Meanwhile, the lack of clarity in public ownership will negatively affect the motivation of executives, important decisions of firms and dealing with the consequences of decisions brought about by collective ownership.

\subsubsection{Agency Theory}

The representation theory is considered the fundamental theory related to operational performance. This theory shows the relationship between the representatives and owners; it was first articulated by Jensen and Meckling (1976), then later further developed by Fama and Jensen (1983). According to this theory, because some executives have special skills and better knowledge of company management than the owners, owners are willing to hire and delegate management responsibilities and the rights of making control decision to them (Fama \& Jensen, 1983). Agents, on behalf of the owners, carry out the management of the company, but only receive the majority of their benefits from salaries. However, both of these entities may want to maximize their benefits, and conflict of interest may arise. To reduce this conflict and improve the operational performance of the company, the owners must accept agency costs (Jensen \& Mecklong, 1976). Agency cost is defined as the total of cost categories including (i) the cost of control, which is the cost paid to the controllers to inform shareholders when the executives have profiteering activities for their own benefits, (ii) binding costs are the costs to prevent the negative consequences that may occur from the dishonest actions of executives, and (iii) the additional losses, which are charges related to damages caused by their agents who use their power for personal gain.

\subsection{Research Model}

Based on the literature reviewed, the proposed research model is as follows:

$$
\begin{aligned}
\mathrm{FP}= & \beta_{0}+\beta_{1} \mathrm{FO}+\beta_{2} \mathrm{FM}+\beta_{3} \mathrm{GROW}+\beta_{4} \mathrm{AGE}+\beta_{5} \mathrm{SIZE} \\
& +\beta_{6} \mathrm{LIQ}+\beta_{7} \mathrm{LEV}+\varepsilon
\end{aligned}
$$

In which:

The dependent variable is financial performance (FP) is measured by Tobin's Q, ROA and ROE.

- Tobin's $Q$ : This is the market value of firms which is calculated by the market value of capital/ the book value of capital

- ROA: This is a measure of financial performance calculated by dividing net income by assets.

- ROE: This is a measure of financial performance calculated by dividing net income by shareholders' equity

\section{Independent variables include:}

- Foreign ownership (FO): This is the ownership ratio of foreign investors and is calculated by the total number of shares held by foreign shareholders divided by the total number of outstanding shares

- Foreign management (FM): This is the management participation of foreigners in firms and is measured by the number of foreigners participating in management in firms. 


\section{Control variables include:}

- Revenue growth rate (GROW): This is the growth rate of net revenue, which is calculated by subtracting the net revenue of the previous year from the net revenue of the following year, then then dividing by the net revenue of the previous year.

- The age of the firm (AGE): This indicates the years of operation of firms since establishment until the year of study.

- The size of the firm (SIZE): This shows how big a firm is and is calculated by logarithm of total assests.

- Liquidity (LIQ): This is the payment ability of a firm and is calculated by dividing short-term asset by total liabilities

- Financial leverage (LEV): This shows the financial capital structure of a firm and is calculated by dividing total liabilities by total assets.

\subsection{Hypothesis}

According to ownership theory, agency theory and previous studies, the hypotheses about the impact of foreign ownership and management as well as and control variables on financial performance are formulated as follow:

\subsubsection{Foreign Ownership Ratio}

According to the ownership theory, ownership motivates firms to make the most efficient use of resources to maximize profits. Results of previous studies show that a capital investment/contribution relationship often goes beyond financial contributions and extends to training, management transfer, and technical cooperation. A number of studies in different countries also show a positive relation between the foreign ownership ratio and financial performance of firms such as Olga (2009), Chibber and Majumdar (1999), Douma et al. (2006), Vu et al. (2019), Nguyen and Dang (2017). In contrast to the above studies, some authors such as Xu and Wang (1999), Lee (2008), Abbas et al. (2009), and Nguyen (2018) found no indication that foreign ownership ratio was correlated with financial performance of firms. The hypothesis of the independent factor that foreign ownership ratio affects financial performance is created as follows:

H1: The foreign ownership ratio has a positive impact on financial performance

\subsubsection{Foreign Management}

According to previous studies, the presence of foreigners in the corporate management system may bring competitive advantages to firms through expanding international networks (Oxelheim \& Randoy, 2003), widen the consumption market and improve business efficiency. Moreover, foreigncontrolled companies can arrange technical cooperation, nominate foreign directors on the board, arrange activities of consultancy and marketing, branding, patent obligations and share management resources (Dhar et al., 1988) help improve financial efficiency. Research results of Oxelheim and Randoy (2003), Ruigrok and Kaczmarek (2008), Choi et al. (2007) show that financial performance of firms with members of diverse nationalities in top management is higher than that of local firms. Contrary to this assumption, the study by Rose (2007) found no evidence of the impact of foreign management on financial performance. The hypothesis of the impact of foreign management on financial performance is as follows:

H2: Foreign management has a positive impact on financial performance

\subsubsection{Control Variables}

Growth is one of the basic conditions for firms to achieve their goals during production and business activities. Growth helps firms accumulate capital and facilities to invest in expanding production and build credibility with customers as well as with suppliers, investors. According to previous studies, firms with high growth rates often have good financial performance growth can help generate profits from investment. Research by Ntim and Osei (2011), Costea (2012) showed that revenue growth has positive impact on ROA but negative impact on ROE. In Vietnam, however, the research results by Huynh (2016) showed a positive relationship to both ROA and ROE variables. The hypothesis for the revenue growth variable in this research is:

H3: Revenue growth rate has a positive impact on financial performance

According to previous studies, firms have been operating for a long time can accumulate a lot of capital to finance their business activities as well as new investment projects. At the same time, these firms often have a lot of experience and gain credibility and extensive social relationships with other firms or commercial banks. As a result, it is easy for them to have access to capital and information related to their business operation; their operation efficiency is also high. Studies by Gurbuz and Aybars (2012); Maleya et al. (2013) showed that the longer a firm operates, the higher the financial performance, but Chhibber and Majumdar (1999) and Huynh (2016), Homaidi et al (2020) indicated the opposite. Therefore, the authors proposed the hypothesis for the impact of age of firm on financial performance as follows: 
H4: Age of firm as a positive impact on financial performance

The size of firm is important to business performance because it represents a firm's resources. According to Doan (2014), large firms with well-organized resources and goodquality machinery and equipment easily achieve their goals. Empirical research results show that, regardless of the group of criteria to evaluate the efficiency, there are three different directions. According to Huang and Wang (2011), the larger the firm size, the higher the financial performance because such firm has advantages in finance, organizational structure, technology level. But Lauterbach and Vaninsky (1999), Tian and Zeitun (2007) found no indication of the impact of firm size on financial performance. Based on previous research results, the authors created the hypothesis for the factor of firm size by asset as follows:

H5: Firm size has a positive impact on financial performance.

The international financial reporting standards (2006) define liquidity as cash available in the near future, taking into account the related financial obligations in that period. Liargovas and Skandalis (2008) argued that firms may use current assets to finance their activities and investments when external financial resources are not available. Almajali et al. (2012) found that liquidity has a significant impact on financial performance. But, in contrast to the above argument, the theoretical model of Jovanovic (1982) suggests that a moderate amount of liquidity can boost business performance, but having too much liquidity may be detrimental to business efficiency. The hypothesis for this factor is set as follows:

H6: Liquidity has a positive impact on financial performance

According to Quan and Ly (2014), a typical characteristic of Vietnamese firms is that they often have very high debt ratios, which significantly affects business performance. High debt ratios lead to increasing interest expenses and reducing profits, which has a significant impact on ROA and ROE. According to Berger and Patti (2006), financial leverage has a positive effect on dependent variables about financial performance. On the other hand, Astami et al. (2010), Chu Thi Thu Thuy et al. (2015), Nguyen and Nguyen (2020) suggested that financial leverage has negative impact on financial performance. However, according to Alipour (2012), financial leverage has a positive impact on ROE and negative impact on ROA and ROS. As studies with different spaces yielded conflicting results, the authors put the leverage variable into the model and set up the 7 th hypothesis as follows:

\section{H7: Financial leverage has a positive impact on financial performance}

\subsection{Data}

To achieve the research objectives according to the above model, the authors use the data source that included information about financial statements and related information of firms listed on the Vietnamese stock market during the 2014-2018 period. According to the research purpose and scope, the authors removed firms in the financial sector and those with insufficient data in the research sample. After collecting and synthesizing data, the total number of firms in the sample was 427 ; these firms had enough data and meet information requirements.

\subsection{Research Method}

The verification process of these models was carried out in turn through such tests as descriptive statistics and multicollinearity tests. Each model was verified using Pooled OLS, REM and FEM methods. The selection of an effective model was done by Hausman or Lagrange test; after that autocorrelation and variance of variance were tested and the general regression model (GLS) was used to correct defects and draw conclusions.

\section{Research Results}

\subsection{Descriptive Statistics}

Using thes Stata software, the dependent, independent and control variables in the model are summarized on Table 1.

- The average Tobin's Q coefficient of firms in the survey sample was 1.16, which proved that firms were rated on the market higher than their book value. In particular, the highest-rated firm was rated 10.176 times higher than its book value, while the lowest-rated firm was rated as 0.093 times of its book value.

- The average ROA of firms in the research sample was 0.069 with the highest ROA of 0.72 and the lowest ROA of -0.99 .

- The average ROE of firms in the research sample was 0.132 with the highest ROE of 1.61 and the lowest ROE of -1.69 .

- The average foreign ownership ratio of firms in the research sample was $13.41 \%$ with the highest investment ratio of $78 \%$ and the lowest of $0 \%$. 
Table 1: Descriptive Statistics of variables in the model

\begin{tabular}{|l|c|c|c|c|c|}
\hline Variable & Obs & Mean & Std.Dev. & Min & Max \\
\hline TobinQ & 2135 & 1.1589 & .83024 & .093 & 10.176 \\
\hline ROA & 2135 & .06888 & .08223 & -.99 & .72 \\
\hline ROE & 2135 & .13172 & .15388 & -1.69 & 1.61 \\
\hline FO & 2135 & .12467 & .13819 & 0 & .78 \\
\hline FM & 2135 & .25340 & .75794 & 0 & 6 \\
\hline GROW & 2135 & .19818 & .77907 & -1.039 & 9.556 \\
\hline AGE & 2135 & 11.44965 & 3.74556 & 0 & 25 \\
\hline SIZE & 2135 & 27.24204 & 1.74806 & 21.219 & 33.294 \\
\hline LIQ & 2135 & 2.591593 & 3.77742 & .05 & 67.14 \\
\hline LEV & 2135 & .4787246 & .21796 & .006 & .993 \\
\hline
\end{tabular}

- The average number of foreign members in the board of directors or board of management of firms in the research sample was 0.25 people. In the research sample, the highest number of foreign board members in firms was 6 .

- The average revenue growth rate of firms in the search sample was $19.81 \%$ with the highest rate of $955,6 \%$ and the lowest rate of $-103.9 \%$.

- The average age of firms in the research sample was 11,45 years. There was even a firm which has been in operation for 25 years by 2018 .

- The scale of firms according to the natural logarithm of the total assets was the average of 27.24 with the highest value of 33.294 and lowest value of 21.219.

- The average liquidity of firms in the research sample reached 2.59 times. There were firms with very low liquidity at 0.05 times and those with overly high liquidity of 67.14 times.

- The average financial leverage of firms was 0.478 . There were firm using very little loans, only at 0.006 , and those used most of loans for their production activities (0.993).

\subsection{An Empirical Model}

The authors used Pooled OLS, REM and FEM, methods as well as the Hausman test to choose a suitable model between FEM and REM. Test results of two dependent variables are shown in Table 2. The significant value of three models were all $<0,05$, showing that the FEM model was more suitable than the REM model. As a result, the FEM model was selected for further tests.

\subsection{Defects of the Model}

Once the FEM model was selected for all three dependent variables, the authors examined the model's defects including multicollinearity, autocorrelation, and variance of variance.
Table 2: Results of Hausman test on ROA, ROE models

\begin{tabular}{|l|c|c|c|}
\hline & Tobin's Q & ROA & ROE \\
\hline Statistical value & 39.99 & 45.79 & 65.28 \\
\hline Sig & 0.0000 & 0.0000 & 0.0000 \\
\hline
\end{tabular}

Table 3: Variance Inflation Factor

\begin{tabular}{|l|c|c|}
\hline Variable & VIF & $\mathbf{1 / V I F}$ \\
\hline LEV & 1.58 & 0.63329 \\
\hline FO & 1.44 & 0.69503 \\
\hline SIZE & 1.35 & 0.74249 \\
\hline FM & 1.34 & 0.74595 \\
\hline LIQ & 1.33 & 0.75136 \\
\hline AGE & 1.04 & 0.96382 \\
\hline GROW & 1.02 & 0.98063 \\
\hline Mean VIF & 1.30 & \\
\hline
\end{tabular}

\section{Multicollinearity:}

The authors used the Variance inflation factor (VIF) to test multicollinearity with the following results (see Table 3 ). The VIF factors of all variables in the model were $<10$, proving that multicollinearity didn't occur with variables in all three models.

\section{Autocorrelation:}

The authors used the Wooldridge test for autocorrelation in each model with the following results (see Table 4). The test results show that autocorrelation occured in the Tobin's $\mathrm{Q}$ and ROA models, but not in ROE models. To overcome autocorrelation, the authors used a stronger regression model (GLS). 


\section{Variance of variance:}

Wih FEM as the chosen model, the authors used Wald test for variance of variance in research models with the following results (see Table 5). Test results show that variance of variance occurred in all three models. The authors used the GLS model to overcome this defect.

\subsection{Regression}

The GLS model was used for all three dependent variables. Autocorrelation and variance of variance were fixed in the Tobin's Q and ROA models while only variance of variance was fixed in the ROE model. Regression results of three models are shown in Table 6.

\subsection{Discussion}

According to the research results of 427 fims listed on the Vietnamese stock market, foreign ownership ratio does not show signs of impact on Tobin's Q; however, it has a positive impact on the ROA and ROE. This result is consistent with the research results by Olga (2009), Chibber and Majumdar (1999), Douma et al. (2006); Dinh and Ho (2017).

Table 4: Test results of autocorrelation

\begin{tabular}{|l|c|c|c|}
\hline Variable & TobinQ & ROA & ROE \\
\hline F & 32.35 & 4.713 & 0.071 \\
\hline P value & 0.0000 & 0.0306 & 0.7897 \\
\hline
\end{tabular}

Table 5: Results of variance of variance test

\begin{tabular}{|l|c|c|c|}
\hline Variable & TobinQ & ROA & ROE \\
\hline Chi2 & 4.7 & 3.2 & 2.1 \\
\hline Sig & 0.0000 & 0.0000 & 0.0000 \\
\hline
\end{tabular}

Foreign management has positive impact on Tobin's Q. This conclusion is consistent with research results by Choi et al. (2007) and Oxelheim and Randoy (2003). In fact, according to previous studies, when listing on the stock exchange, firms also want to improve financial performance to attract more investment (Nguyen \& Nguyen, 2013). At the same time, the participation of foreign investors increases the reputation of firms in domestic and international markets, helping to improve their market value.

However, foreign management has negative impact on ROA and ROE (with ROA, the reliability was only at $90 \%$ ); such result is consistent with research results by Rose (2007), Joenoes and Rokhim (2019), but contrary to those by Oxelheim and Randoy (2003), Ruigrok and Kaczmarek (2008), and Choi et al. the (2007). This is probably because foreign management does not necessarily mean that foreign investors participated in management and firms hired foreigners in the international market to run and manage the busines. As a result, management costs will be higher than hiring a local executive. In addition, with improving technology, the quality of services and products or increasing training costs also put more pressure on firms, leading to a decline in the profitability. Moreover, the Ministry of Planning and Investment's surveys on FDI firms in recent years have shown that on average, $70 \%$ of FDI firms declare annual losses due to transfer pricing or a number of FDI firms make profits but have very low ROS ratio. Firms with foreign management maybe able control and adjust the profit so their financial performances are not high.

Revenue growth has negative impact on Tobin's Q and ROA, but was positively related to ROE. This result is consistent with the research results on ROE variables by Huynh (2016), but contrast with the research results by Ntim and Osei (2011) and Costea (2012). In fact, the revenue growth rate of firms reflects the economic potential, stability and the growth of firms, thereby increasing profits for firm

Table 6: GLS results

\begin{tabular}{|l|c|c|c|c|c|c|}
\hline \multirow{2}{*}{ Variable } & \multicolumn{2}{|c|}{ Tobin Q } & \multicolumn{2}{c|}{ ROA } & \multicolumn{2}{c|}{ ROE } \\
\cline { 2 - 6 } & Beta & Sig & Beta & Sig & Beta & 0.000 \\
\hline FO & 0.0491 & 0.105 & $0.0320^{* * *}$ & 0.000 & $0.1040^{* * *}$ & 0.000 \\
\hline FM & $0.0186^{* * *}$ & 0.003 & $-0.0023^{*}$ & 0.053 & $-0.0080^{* * *}$ & 0.000 \\
\hline GROW & $-0.0061^{* *}$ & 0.035 & $-0.0089^{* * *}$ & 0.000 & $0.0214^{* * *}$ & $-0.0024^{* * *}$ \\
\hline SIZE & $-0.0062^{* * *}$ & 0.000 & $-0.0010^{* * *}$ & 0.000 & 0.000 \\
\hline LIQ & -0.0033 & 0.189 & 0.0008 & 0.134 & $0.0033^{* * *}$ & 0.000 \\
\hline LEV & $-0.0033^{* * *}$ & 0.005 & $-0.0008^{* *}$ & 0.020 & $-0.0029^{* * *}$ & 0.000 \\
\hline Cons & -0.0169 & 0.466 & $-0.1270^{* * *}$ & 0.000 & $-0.0650^{* * *}$ & 0.000 \\
\hline R-Square & $1.2069^{* * *}$ & 0.000 & $0.1112^{* * *}$ & 0.000 & $0.0894^{* * *}$ & 0.000 \\
\hline
\end{tabular}

Note: ${ }^{* * *},{ }^{* *}$ and ${ }^{*}$ indicates significant at $1 \%, 5 \%$ and $10 \%$ level of significance based on t-statistics 
owners. However, when firms have high revenue growth rates and they expand investment activities or pay dividends by shares, the owner's equity is diluted while the market value of capital does not keep pace with the equity growth rate. This may cause the enterprises' Tobin's Q coefficient to decrease.

Surprisingly, the research results show that the age of firm has negative impact on all three measurement variables of financial performance of firms. This means that the higher the age of a firm, the lower the market value of capital and profitability. This research result is similar to those by Chhibber and Majumdar (1999), Huynh (2016), but contradict those by Gurbuz and Aybars (2012), Maleya et al. (2013), Nguyen and Ngo (2017). According to Huynh (2016), the longer the firms operate in the market, the more stagnant they become and do not switch timely to highperforming industries and fields. Besides, the society is growing; new fields and markets are constantly developing. Young firms may be able to seize the opportunities and find ways to penetrate the market, so they constantly built up reputation and improve product quality in order to exist and develop. Therefore, the age of firm is not a factor that helps a firm improve its financial performance.

Size of a firm positively affects ROE, but does not show any signs of impact on Tobin's Q and ROA. This result is consistent with the research results by Gurbuz and Aybars (2012), Maleya et al. (2013), but contrary to the research results by Nguyen and Ngo (2017). This can be explained by the fact that, if firms invest in expanding their sized, especially increasing fixed assets, they will help firms produce products with higher quality, aesthetics, and taste. In addition, firms with bigger size have better reputation than those of small sizes and also better competitive edges; this can help firms improve their profit and financial performances.

Liquidity of a firm has a negative impact on all three measurement scales of financial performance. This result is consistent with the research results by Almajali et al (2012), Nguyen and Ngo (2017), but contrary to the results by Paris (2010). For firms, short-term liquidity is a very important indicator for company executives. However, according to this research result, liquidity ratio of firms is very high (2.56 times), which means firms have too many short-term assets compared to short-term liabilities. This can lead to inefficient use of short-term assets and may become an indirect cause of financial performance decline.

Financial leverage has a negative impact on financial performance of firms. This result is consistent with the results by Zeitun and Tian (2007), Nguyen and Nguyen (2013), but is contrary to the results by Nguyen and Ngo (2017). It can be seen that firms in Vietnam typically have very high debt ratios, which can theoretically be a lever to amplify the profits of businesses, but also cause an increase in interest expenses and eventually a decrease in profit. In addition, a high debt ratio may affect the ability of a firm to get loans and the pressure to pay interest and principal will make it difficult for a firm to operate.

\section{Conclusions and Recommendations}

The authors studied and collected data of 427 listed companies on the Vietnamese stock market from 2014 to 2018. After performing the necessary tests to select and overcome the defects of the OLS, FEM and REM models, the authors used GLS test to assess the impact of foreign ownership and management on financial performance. The results show that foreign ownership ratio positively affects ROA and ROE, but shows no signs of impact on Tobin's Q; foreign management has a positive impact on Tobin's Q, but negatively impact on ROA and ROE. Regarding control variables, revenue growth and financial leverage show no signs of impact on Tobin's Q, but has negative impact on ROA and ROE. The size of the firm alone does not affect both Tobin's Q and ROA; liquidity has a negative impact on all three measurement scales.

Through the research results, in order to improve the financial performance of listed companies on Vietnamese stock market, the authors present the following recommendations:

Firstly, firms need to be transparent and disclose their business results in accordance with current regulations and with the approach of international standards (IFRS). Transparency and disclosure of information will help firms improve their reputation in the market. At the same time, it helps foreign investors analyze information of firms more accurately and attract more investment capital from these investors.

Secondly, firms need to proactively build specific business strategies and plans to attract investors, while offering reasonable dividend policies to encourage foreign investors.

Thirdly, firms need to strictly control indirect capital into their units, monitor the moves of professional investors, co-operate with the government and the financial, banking supervision system to effectively manage indirect capital.

Fourthly, firms should consider increasing the number of Vietnamese members on the board of directors and board of management and limit hiring non-Vietnamese nationals to join these boards. If necessary, firms should only hire a team of foreign experts for a certain period of time for certain situations and projects; domestic human resources should be utilized for the whole process of administration and management. 


\section{Reference}

Abbas, S., Rahman, R., \& Mahenthiran, S. (2009). Ultimate Ownership and Performance of Islamic Financial Institutions in Malaysia. In: Asian Finance Association Conference. July 2009, Brisbane, Australia. https://ssrn.com/abstract=1392833

Alipour, M. (2012). Has privatization of state-owned enterprises in Iran led to improved performance?. International Journal of Commerce and Management, 23(4), 281-305. https://doi. org/10.1108/IJCoMA-03-2012-0019

Almajali, Y. A., Alamro, S. H., \& Al-Soub, Y. Z. (2012). Factors Affecting the Financial Performance of Jordanian Insurance Companies Listed at Amman Stock Exchange. Journal of Management Research, 4(2), 226-289. doi:10.5296/jmr. v4i2.1482

Astami, E. W., Tower, G., Rusmin, R., \& Neilson, J. (2010). The effect of privatisation on performance of state-ownedenterprises in Indonesia. Asian Review of Accouting, 18(1), 5-19. https://doi.org/10.1108/13217341011045971

Baek, J. S., Kang, J. K., \& Park, K. S. (2004). Corporate Governance and Firm Value: Evidence from the Korean Financial Crisis. Journal of Financial Economics, 71(2), 265-313, https://doi. org/10.1016/S0304-405X(03)00167-3

Berger, A. N., \& di Patti, E. B. (2006). Capital structure and firm performance: A new approach to testing agency theory and an application to the banking industry. Journal of Banking \& Finance, 30(4), 1065-1102. https://doi.org/10.1016/j. jbankfin.2005.05.015

Choi, J. J., Park, S. W., \& Yoo, S. S. (2007). The value of outside directors: evidence from corporate governance reform in Korea. Journal of Financial and Quantitative Analysis, 42(4), 941-962. https://www.jstor.org/stable/27647330

Chibber, P. K., \& Majumdar, S. K. (1999). Foreign Ownership and Profitability: Property Rights, Control, and the Performance of Firms in Indian Industry. The Journal of Law and Economics, 42, 209-238. https://doi.org/10.1086/467423

Chu, T. T. T., Nguyen, T. H., \& Ngô, T. Q. (2015). The factors affecting firms' financial perfomance: the case of non-financial companies listed on HoChiMinh stock exchange. Journal of Economic and Development, 215, 59-66.

Costea, V. (2012). Determinants of coporate financial performance. Retrieved April 20, 2020 from: www.dafi.ase.ro/revista/6/ Costea\%20Valentin.pdf

Darmadi, S. (2010). Board diversity and firm performance: the Indonesian evidence. Corporate Ownership and Control, 8(24), 450-466. http://dx.doi.org/10.22495/cocv8i2c4p4.

Dinh, T. T., \& Ho, X. T. (2017). The Relation between Ownership Types and Business Efficiency: A Case study of Post-equitisation Firms listed on the Vietnamese Stock Market. Vietnam Trade and Industry Review, 4(5), 238-245. [Vietnamese]

Doan, N. P. (2014). Improving Business Efficiency of Postequitisation State-owned Firms in Vietnam. Doctoral thesis. University of Economics Ho Chi Minh City. [Vietnamese]
Dhar, V., Mager, D., Iqbal, A. 1., \& Schildkrautl, C. I. (1988). The Coordinate Replication of the Human 3-Globin Gene Domain Reflects Its Transcriptional Activity and Nuclease Hypersensitivity. Molecular and Cellular Biology, 8(11), 49584965. DOI: 10.1128/MCB.8.11.4958

Djankov, S., \& Hoekman, B. (2000). Foreign Investment and Productivity Growth in Czech Enterprises. The World Bank Economic Review, 14(1), 49-64. https://doi.org/10.1093/ wber/14.1.49

Douma, S., George, R., \& Kabir, R. (2006). Foreign and domestic ownership, business groups and firm performance: Evidence from a large emerging market. Strategic Management Journal, 27(7), 637-657. https://doi.org/10.1002/smj.535

Estrin, S., Hanousek, J., Kocenda, E., \& Svejnar, J. (2009). The Effects of Privatization and Ownership in Transition Economies. Journal of Economic Literature, 47(3), 699-728. DOI: $10.1257 /$ jel.47.3.699

Gurbuz, A.O. \& Aybars, A. (2010). The impact of foreign ownership on Firm Performance, evidence from an: Emerging market: Turkey. American Journal of Economics \& Business Administration, 2(4), 350-359.

Greenaway. D., Guariglia. A., \& Zhihong. Y. (2014). The more the better? Foreign ownership and corporate performance in China. The European Journal of Finance, 20(7-9), 681-702. https:// doi.org/10.1080/1351847X.2012.671785

Homaidi, E. A., Tabash, M. I., Ahdal, W. M. AL, Farhan, N. H. S., \& Khan, S. H. (2020). The Liquidity of Indian Firms: Empirical Evidence of 2154 Firms. Journal of Asian Finance, Economics and Business, 7(1), 19-27. https://doi.org/10.13106/jafeb.2020. vol7.no1.19

Huynh, T. T. P. (2016). A Study of Factors Affecting Operational Efficiency of Listed Firms. Review of Finance, 1/2016, 47-50.

Joenoes, M. Z., \& Rokhim, R. (2019). Does foreign board increase the company's performance? The evidence from Indonesia. Journal of Economics, Business, and Accountancy Ventura, 22(2), 213-222. http://dx.doi.org/10.14414/jebav.v22i2.1449

Jovanovic. B., (1982). Selection and the Evolution of Industry, Econometrica, 50(3), 649-670. DOI: 10.2307/1912606

Lauterbach, B. \& Vaninsky, A. (1999). Ownership structure and firm performance: Evidence from Israel. Journal of Management, 3(2), 189-201. https://doi.org/10.1023/A:1009990008724

Lee, S. (2008). Ownership Structure and Financial Performance: Evidence from Panel Data of South Korea. Corporate Ownership \& Control, 6(2), Winter 2008. http://hdl.handle. net $/ 10419 / 64457$

Liargovas, P., \& Skandalis, K. (2008). Factor affecting firms' financial performance: The Case of Greece. Global Business and Management Research: An International Journal, 2(2\&3), 184-197.

Maleya M. O., \& Muturi, D.W. (2013). Factors Affecting the Financial Performance of Listed Companies at the Nairobi Securities Exchange in Kenya. Research Journal of Finance and Accounting, 4(15), 99-105. 
Nguyen, A. P. \& Ngo, P. T. (2017). The Impact of Scale and Foreign Ownership on Operational Efficiency. Hue University Journal of Science: Economics and Development, 5(C), 75-85. [Vietnamese]

Nguyen, M. H., \& Nguyen, T. D. P. (2013). The Impact of Foreign Ownership on Operational Efficiency of Listed Firms on the Vietnamese Stock market. Review of World Economic and Political Issues, 4(204), 70-80. [Vietnamese]

Nguyen, T. X. M. (2018). Factors Affecting the Operation of Companies on the Vietnamese Stock Market. Vietnam Trade and Industry Review, 13, 376-381. [Vietnamese]

Nguyen, V. T., \& Pham, T. Q. (2017). The impact of Shareholder Ownership on Stock Profit of Listed Firms in Vietnam. Journal of Economics and Development, 242, 26-35.

Nguyen, T. M. H., \& Dang, T. L. (2017). Impact of Ownership Structure on Operational Efficiency of Listed Firms on the Vietnamese stock market. VNU Journal of Science: Economics and Business, 33(1), 23-33. [Vietnamese]

Nguyen, H. T., \& Nguyen, H. A. (2020). The Impact of Capital Structure on Firm Performance: Evidence from Vietnam. Journal of Asian Finance, Economics and Business, 7(4), 97105. https://doi.org/10.13106/jafeb.2020.vol7.no4.97

Ntim, C. G., \& Osei. A. C. (2011). The Impact of Corporate Board Meetings on Corporate Performance in South Africa. African Review of Economics and Finance, 2(2), 83-103. https://www. ajol.info/index.php/aref/article/view/86950

Olga B. (2009). Foreign Ownership And Firm Performance: A Closer Lookat Offshore Owned Companies in Ukraine. Master Thesis. Kyiv School of Economics. Available at: http://www. kse.org.ua/uploads/file/Bilyk_thesis_final.pdf

Oxelheim, L., \& Randøy, T. (2003). The impact of foreign board membership on firm value. Journal of Banking and Finance, 27(12), 2369-2392. https://doi.org/10.1016/S03784266(02)00395-3

Paris, A. (2010). The Evolution of capital Productivity in Greek Manufacturing. Global Business and Management Research: An International Journal, 2(2\&3), 141-161.

Park, K. (2002). Foreign ownership and firm value in Japan. CEI Working Paper Series 2002-15. Center for Economic Institutions,
Institute of Economic Research, Hitotsubashi University. Kunitachi, Japan. https://hdl.handle.net/10086/13896

Park, Y. S. (2004). Assessing the Impact of Corporate Governance on Productivity and Growth in Korea. Retrieved June 10, 2020 from: https://www.apo-tokyo.org/wp-content/uploads/sites/5/ ind-05-icgp.pdf\#page $=205$.

Quan, M. N., \& Lý, T. P. T., (2011). Analysis of factors affecting the performance of real estate enterprises listed on Vietnam's stock market. Cantho University Science Journal, 33, 65-71. [Vietnamese]

Rose, C. (2007). Does female board representation influence firm performance? The Danish evidence. Corporate Governance: An International Review, 15(2), 404-413, https://doi.org/10.1111/ j.1467-8683.2007.00570.x

Ruigrok, W., \& Kaczmarek, S. (2008). Nationality and international experience diversity and firm performance: country effects. Working Paper. University of St. Gallen, St. Gallen, Switzerland.

Tian, G. G., \& Zeitun, R. (2007). Capital Structure and Corporate Performance: Evidence from Jordan. Australasian Accounting Business and Finance Journal, 1(4), 40-61. doi:10.14453/ aabfj.v1i4.3

Saleh, N. M., Rahman, M. R. C. A., \& Hassan, M. S. (2009). Ownership structure and intellectual capital performance in Malaysia. Asian Academy of Management Journal of Accounting and Finance, 5(1), 1-29.

Vu, T. T. V., Phan, T. N., \& Dang, N. H. (2019). Impacts of Ownership Structure on Systemic Risk of Listed Companies in Vietnam. Journal of Asian Finance, Economics and Business. 7(2), 107-117. https://doi.org/10.13106/jafeb.2020.vol7. no2.107

Wei, Z., Xie, F., \& Zhang, S. (2004). Ownership Structure and Firm Value in China's Privatized Firms: 1991-2001. Journal of Financial and Quantitative Analysis, 40(1), 87-108. https://doi. org/10.1017/S0022109000001757.

Xu. X., \& Wang Y. (1999). Ownership structure and corporate governance in Chinese stock companies. China Economic Review, 10(1), 75-98. https://doi.org/10.1016/S1043951X(99)00006-1 